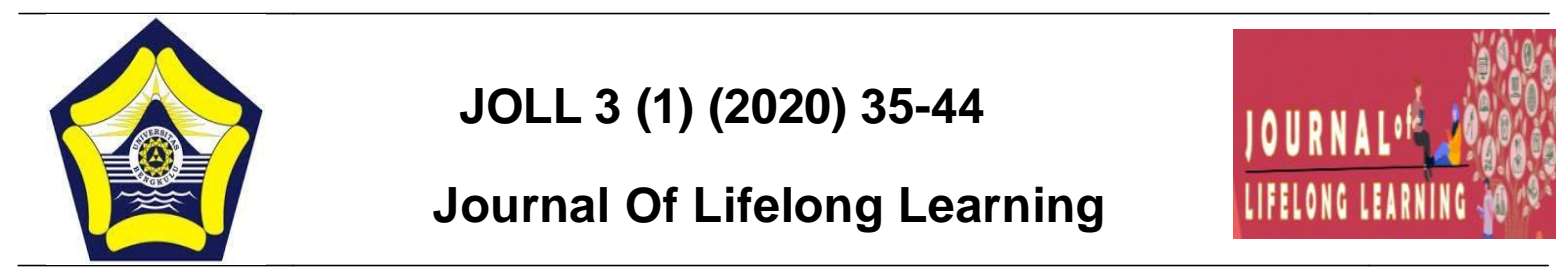

\title{
UPAYAH UNTUK MENGEMBANGKAN KETERAMPILAN KERAJINAN TANGAN
}

\author{
Erik Suganda Syaputra' ${ }^{1}$, Wahiruddin Wadin ${ }^{2}$, Parlan $^{3}$ \\ ${ }^{1}$ Erik Suganda Syaputra, Universitas Bengkulu, Indonesia, eriksuganda294@gamail.com \\ ${ }^{2}$ Wahirudin Waddin, Universitas Bengkulu, Indonesia, waharidinwaddin@gmail.com \\ ${ }^{3}$ Parlan, Universitas Bengkulu, Indonesia, parlanunib@gmail.com
}

\begin{abstract}
The purpose of this research is to describe understanding by new students of nonformal education at Bengkulu University about nonformal education. As for the scope studied in this research was students understanding about the scope nonformal education which consist of understanding, characteristics, goals, roles, programs, institution and education facilities . Furthermore, reviewing the understanding of students at bengkulu university about the graduate competence and employment opportunity of S1 non formal education. The design of this research was descriptive quantitatif research, this method carried out with the main goal to make an idea of situation objectively, the respondents of this research were new students of non formal education study program at Bengkulu University. The result and discussion of this research that understanding of new students of non formal study program at Bengkulu University about scope of informal education was high enough with percentage $69.4 \%$, understanding about the graduate competence of S1 non formal education was sufficient with percentage $51 \%$ and understanding about employment opportunity of S1 non formal education was highwith percentage $67.5 \%$
\end{abstract}

Key words : understanding, eldery work

C2020 DeptofNonformalEducationUNIB ISSN :2715-9809

\section{Addresscorrespondence:}

Jl.W.R.Supratman,KandangLimun,MuaraBangkaHulu, KotaBengkulu,Bengkulu38371 


\section{PENDAhuluan}

Pendidikan merupakan kebutuhan dasar manusia yang harus terpenuhi, maka dari itulah pemerintah mengatur hal ini sedemikian rupa, baik dalam aturan undang-undang maupun kebijakan-kebijakan agar setiap individu berhak dan mendapatkan pendidikan. Dalam Kamus Besar Bahasa Indonesia (KBBI), "Pendidikan diartikan sebagai proses pengubahan sikap dan tata laku seseorang atau kelompok orang di usaha mendewasakan manusia melalui upaya pengajaran dan pelatihan". Tentukan kemudian, dalam arti luas, pendidikan adalah segala bentuk pengalaman belajar yang berlangsung dalam lingkungan keluarga, sekolah dan masyarakat untuk mengembangkan kemampuan seoptimal mungkin sejak lahir sampai akhir hayat. Dalam arti sempit, pendidikan identik dengan persekolahan tempat pendidikan dilakukan dalam bentuk kegiatan pembelajaran yang terprogram dan terencana secara formal.

Pendidikan adalah usaha sadar dan terencana untuk mewujudkan suasana belajar dan proses pembelajaran agar peserta didik secara aktif mengembangkan potensi dirinya untuk memiliki kekuatan spiritual keagamaan, pengendalian diri, kepribadian, kecerdasan, akhlak mulia, serta keterampilan yang diperlukan dirinya, masyarakat, bangsa dan negara. Adapun sistem pendidikan yang ada di Indonesia menurut Undang-Undang No. 20 Tahun 2003 pasal 13 ayat 1 menegaskan bahwa, " jalur pendidikan terdiri atas pendidikan formal, nonformal dan informal yang dapat saling melengkapi dan memperkaya". Pasal 1 Ayat 12 :Pendidikan Non Formal adalah "jalur pendidikan diluar pendidikan formal yang dapat dilaksanakan secara terstruktur dan berjenjang".

Jalur Pendidikan diselenggarakan bagi warga masyarakat yang memerlukan layanan pendidikan yang berfungsi sebagai pengganti, penambah dan/atau pelengkap pendidikan formal dalam rangka mendukung pendidikan sepanjang hayat.

Pengertian Usaha Kecil Menurut Ina Primiana (2006:22) adalah berbagai usaha yang belum terdaftar, belum tercatat, dan belum berbadan hukum, antara lain petani penggarap, industri rumah tangga, pedagang asongan, 
pedangan keliling, pedagang kaki lima.

Dan pemulung.Sedangkan usaha kecil tradisional adalah usaha yang menggunakan alat produksi sederhana yang telah digunakan secara turun menurun, dan atau berkaitan dengan seni budaya.

Berdasarkan Undang-Undang Republik Indonesia Nomor 9 tahun 1995 tentang Usaha Kecil menyatakan bahwa Usaha Kecil adalah kegiatan ekonomi rakyat yang berskala kecil dan memenuhi kriteria kekayaan bersih atau hasil penjualan tahunan serta kepemilikan sebagaimana diatur dalam undang-undang.

Kriteria kerajinan tangan rumah tangga dalam sebagai berikut :

1. Memiliki kekayaan bersih paling banyak Rp.100.000.000 (Satu Juta Rupiah) tidak termasuk tanah dan bangunan tempat usaha.

2. Memiliki hasil penjualan paling banyak Rp.1.000.000.000,- (Satu Miliar Rupiah)

3. Mendapatkan hasil perbulan Rp.500.000 (Lima Ratus Ribu Rupiah)

4. Usaha produktif milik Warga Negara Indonesia, yang berbentuk badan usaha orang perorangan, badan usaha yang tidak berbadan hukum, atau badan usaha berbadan hukum termasuk koperasi.

5. Bukan berupa anak perusahaan atau cabang perusahaan yang dimiliki, dikuasai atau berafiliasi, baik langsung maupun tidak langsung, dengan Usaha Menengah atau Besar.

Adapun Tjitrosoepomo (1991: 21) mengemukakan pengertian kerajinan dalam arti umum dan budaya sebagai berikut:

1. Arti kata umum, kerajinan adalah sesuatu keterampilan yang menghubungkan dengan suatu pembuatan barang yang harus dikerjakan secara rajin dan teliti, biasanya dikerjakan dengan menggunakan tangan.

2. Arti dalam budaya, kerajinan berhubungan erat dengan sistem upacara kepercayaan, pendidikan, kesenian, teknologi, peralatan bahkan juga mata pencarian.

Di Desa Kota Bumi Seginim Manna Bengkulu Selatan, ada seorang lansia yang kesehariannya berjualan di rumah pada hari sabtu 19 Desember 2018, pukul 15:30 
WIB bertemu dengan Bapak Mersik. Lansia tersebut bernama Bapak Mersik lahir di Seginim, 18 April 1946 yang tinggal di Jalan Desa Kota Bumi Kecamatan Seginim Kabupaten Bengkulu Selatan, Bapak Mersik memiliki 1 orang istri dan delapan orang anak, pekerjaan sehari-hari yang dijalani Bapak Mersik adalah berjualan Kerajinan Tangan Rumah Tangga di rumah, pasar tradisional pada hari senin, dan berjualan dirumah setiap harinya. Kerajinan tangan yang dijual di pasar tersebut merupakan hasil dari anyaman seperti (bubu, kinjar atau kinjagh) yang dibuat Bapak Mersik sendiri, yang berawal berdirinya dari tahun 1997 dia mulai berkerajinan tangan berpenghasilan setiap bulan sekirat Rp.500.000 lima ratus rupiah bersih setiap bulannya, selain kerajinan tangan beliau juga memiliki keahlian di bidang kesenian yaitu seni dendang. Hal ini membuktikan bahwa seseorang mampu melakukan sesuatu kegiatan untuk memenuhi kebutuhan hidupnya.

Maka dari latar belakang di atas, peneliti tertarik untuk meneliti
:"Kemandirian Lansia Dalam Usaha Kecil Kerajinan Tangan Rumah Tangga" (Studi Kasus Bapak Mersik Desa, Kota Bumi Kecamatan, Seginim Manna Bengkulu Selatan)".

\section{Metode}

Penelitian ini diarahkan pada upaya menemukan teori-teori yang bersifat deskriftif Peneliti menggunakan metode penelitian kualitatif dengan pendekatan studi kasuskarena permasalahan yang ada dalam penelitian ini tidak berkenan dengan angka-angka, tetapi menguraikan, menggambarkan dan menyimpulkan suatu kasus secara lebih rinci dan detail tentang Kemandirian Lansia Dalam Usaha Kecil Kerajinan Tangan Rumah Tangga (Studi Kasus Bapak Mersik di Desa, Kota Bumi. Kecamatan Seginim Bengkulu Selatan). Adapun penelitian ini dilaksanakan mulai dari tanggal 05 Juli s.d 01 Agustus 2019.

Teknik pengumpulan data menggunakan teknik wawancara dengan mewawancarai 4 orang subjek, teknik observasi dengan melihat keseharian keluarga kemandirian lansia, dan teknik dokumentasi berupa foto 
kegiatan sepulang dari berjualan di pasar. Selanjutnya untuk teknik validitas data menggunakan Triangulasi Subyek Penelitian, Triangulasi Waktu, Triangulasi Teknik, dan penarikan kesimpulan. Teknik peneliti adalah teknik triangulasi. Teknik triangulasi dipakai untuk mengecek kebenaran data. Peneliti menggunakan teknik triangulasi, triangulasi teknik, dan triangulasi waktu. Teknik analisis data dalam penelitian ini meliputi reduksi data, penyajian data, dan penarikan kesimpulan. Reduksi data dilakukan dengan cara mengumpulkan data hasil observasi, wawancara, dan dokumentasi. Data yang diperoleh kemudian di analisis sehingga memperoleh data yang valid. Data yang disajikan dalam penelitian ini berupa teks deskriptif. Penarikan kesimpulan dalam penelitian ini yaitu berdasarkan hasil penelitianyang sudah diperoleh melalui observasi, wawancara, dan dokumentasi. Penarikan kesimpulan disajikan oleh peneliti dalam bentuk deskripsi.

\section{Hasil dan Pembahasan}

1. Untuk mendeskripsikan apa yang melatar belakangi Bapak Mersik dalam menekuni

\section{kerajinan tangan rumah tangga.}

Temuan peneliti dilapangan mengenai Bapak Mersik adalah berjualan Kerajinan Tangan Rumah Tangga di rumah, pasar tradisional pada hari senin, dan berjualan dirumah setiap harinya. Kerajinan tangan yang dijual di pasar tersebut merupakan hasil dari anyaman seperti (bubu, kinjar/kinjagh) yang dibuat Bapak Mersik sendiri, yang berawal berdirinya dari tahun 1997 dia mulai berkerajinan tangan berpenghasilan setiap bulan sekirat 500.000-1.000.000 lima ratus sampai dengan satu juta rupiah bersih setiap bulannya, selain kerajinan tangan beliau juga memiliki keahlian di bidang kesenian yaitu seni dendang.

Temuan peneliti dilapangan dan teori yang ada adalah Pengertian Kemandirian menurut Masrun (1986:8), kemandirian adalah suatu sikap yang memungkinkan seseorang untuk bertindak bebas, melakukan sesuatu atas dorongan sendiri dan untuk kebutuhannya sendiri tanpa bantuan dari orang lain, maupun berpikir dan bertindak original/kreatif, dan penuh inisiatif, mampu 
mempengaruhi lingkungan, mempunyai rasa percaya diri dan memperoleh kepuasan dari usahanya.

Dari pendapat para ahli diatas penulis menyimpulan bahwa kemandirian merupakan sikap yang memungkinkan seseorang untuk bertindak bebas, melakukan sesuatu atas dorongan sendiri dan kemampuan mengatur diri sendiri, sesuai dengan hak dan kewajibannya sehingga dapat menyelesaikan sendiri masalahmasalah yang dihadapi tanpa meminta bantuan atau tergantung dari orang lain dan dapat menyelesaikan sendiri masalah-masalah yang dihadapi tanpa meminta bantuan atau tergantung dari orang lain dan dapat bertanggung jawab terhadap segala keputusan yang telah diambil melalui berbagai pertimbangan sebelumnya.

Berdasarkan hasil wawancara dari ketiga informan tersebut pada pertanyaan yang sama maka dapat disimpulkan bahwa Bapak Mersik adalah berjualan Kerajinan Tangan Rumah Tangga di rumah, pasar tradisional pada hari senin, dan berjualan dirumah setiap harinya. Kerajinan tangan yang dijual di pasar tersebut merupakan hasil dari anyaman seperti (bubu, kinjar atau kinjagh) yang dibuat Bapak Mersik sendiri, yang berawal berdirinya dari tahun 1997 dia mulai berkerajinan tangan berpenghasilan setiap bulan sekirat 500.000-1.000.000 lima ratus sampai dengan satu juta rupiah bersih setiap bulannya, selain kerajinan tangan beliau juga memiliki keahlian di bidang kesenian yaitu seni dendang.

\section{Untuk mendeskripsikan apakah} ada upaya untuk mengembangkan keterampilan kerajinan tangan rumah tangga tersebut

Temuan peneliti di lapangan adalah awal terbentuknya kerajinan tangan itu pohon bambu itu tidak banyak di manfaatkan oleh masyarakat desa seginim dari itu bapak mersik mempunyai ideh untuk memanfaatkan pohon bambu itu menjadi kerajinan rumah tangga dari ideh bapak mersik tadi usaha bapak berkembang dan bisa di jualkan ke pasar tradisional sehingga menghasilkan untung yang besar sampai bisa menyekolahkan anak bapak.

Temuan peneliti di lapangan dan menurut teori yang ada adalah Menurut Sofiah et all (2011:210) menyatakan secara umum sektor usaha 
kecil memiliki karakteristik sebagai berikut:

a) Sistem pembukuan yang relative sederhana dan cenderung tidak mengikuti kaidah administrasi pembukuan standar.

b) Margin yang cenderung tipis mengingat persaingan yang sangat tinggi

c) Modal terbatas

d) Pengalaman manajerial dalam mengelola perusahaan yang masih terbatas.

e) Skala ekonomi yang terlalu kecil, sehingga sulit mengharapkan ditekannya biaya mencapai titik efisiensi jangka panjang.

f) Kemampuan pemasaran dan negosiasi serta diversifikasi pasar sangat terbatas.

g) Kemampuan untuk memperoleh sumber dana dari pasar modal rendah, mengingat keterbatasan dalam system administrasinya.

Berdasarkan hasil wawancara dari ketiga informan tersebut pada pertanyaan yang sama maka dapat disimpulkan awal terbentuknya kerajinan tangan itu pohon bambu itu tidak banyak di manfaatkan oleh masyarakat desa seginim dari itu bapak mersik mempunyai ideh untuk memanfaatkan pohon bambu itu menjadi kerajinan rumah tangga dari ideh Bapak Mersik tadi usaha bapak berkembang dan bisa di jualkan ke pasar tradisional sehingga menghasilkan untung yang besar sampai bisa menyekolahkan anak bapak.

3. Untuk

mendeskripsikan

Permodalan keuntungan yang diperoleh Bapak Mersik Dari kerajinan tangan tersebut.

Temuan penelitian dilapangan adalah dengan memanfaatkan pohon bambu bapak bisa membuat kerajinan tangan seperti bubu dan kinjar, selain itu juga sumber daya manusia mendukung dengan masyarakat dan anak yang sering kkn disini membantu promosikan hasil karya bapak,beserta anak dan istri yang selalu memberi semangat. Berdasarkan temuan penelitian dilapangan dan teori yang ada yaitu Menurut Imaculata Umiyati (2017 : Adapun usaha menumbuhkan kemandirian adalah :

a. Melakukan latihan-latihan keterampilan. 
b. Berusaha untuk tidak mengandalkan bantuan orang lain.

c. Menanamkan disiplin pribadi yang tinggi.

d. Berusaha untuk percaya pada diri sendiri.

e. Mempunyai keyakinan bahwa dirinya mampu memecahkan masalah yang dihadapi.

f. Menanamkan sikap pantang menyerah dalam menghadapi permasalahan.

Berdasarkan beberapa pendapat diatas penulis menarik kesimpulan bahwa kemandirian adalah segala bentuk kegiatan ataupun usaha yang tidak tergantung pada orang lain dan dapat menjalankan segala sesuatu tidak bergantung kepada pihak lainnya, mampu berinovasi, kreatif, berimajinasi dan bertanggung jawab.

Berdasarkan hasil wawancara dari kedua informan tersebut pada pertanyaan yang sama maka dapat disimpulkan keuntungan yang Bapak Mersik miliki itu sudah cukup itu bisa sampai 3 juta tapi itu juga tergantung pembuatan Bapak Mersik juga.

4. Untuk mendeskripsikan kemana Bapak Mersik menjual hasil kerajinan tangan tersebut.

Temuan peneliti dilapangan adalah kendala atau hambatan yang bapak mersik alami pada saat membukak usaha kerajinan tangan membuat bubu dan kinjar yaitu tempat pemasaranya itu di pasar senin cuman satu kali dalam seminggu. Berdasarkan Temuan peneliti dilapangan dan teori yang ada Ada beberapa faktor yang dapat mempengaruhi kemandirian pada remaja menurut Masrun, (1986:4) yaitu:

a. Usia

Pengaruh dari orang lain akan berkurang secara perlahan-lahan pada saat anak menginjak usia lebih tinggi. Pada usia remaja mereka lebih berorientasi internal, karena percaya bahwa peristiwa-peristiwa dalam hidupnya ditentukan oleh tindakannya sendiri. Anak-anak akan lebih tergantung pada orang tuanya, tetapi ketergantungan itu 
lambat laun akan berkurang sesuai dengan bertambahnya usia.

a. Jenis kelamin

Keinginan untuk berdiri sendiri dan mewujudkan dirinya sendiri merupakan kecenderungan yang ada pada setiap remaja.Perbedaan sifat-sifat yang dimiliki oleh pria dan wanita disebabkan oleh perbedaan pribadi individu yang diberikan pada anak pria dan wanita.Dan perbedaan jasmani yang menyolok antara pria dan wanita secara psikis menyebabkan orang beranggapan bahwa perbedaan kemandirian antara pria dan wanita.

b. Konsep diri

Konsep diri yang positif mendukung adanya perasaan yang kompeten pada individu untuk menentukan langkah yang diambil.Bagaimana individu tersebut memandang dan menilai keseluruhan dirinya atau menentukan sejauh mana pribadi individualnya. Mereka yang mmandang dan menilai dirinya mampu, cenderung memiliki kemandirian dan sebaliknya mereka yang memandang dan menilai dirinya sendiri kurang atau cenderung menggantungkan dirinya pada orang lain.

c. Pendidikan

Semakin bertambahnya pengetahuan yang dimiliki oleh seseorang, kemungkinan untuk mencoba sesuatu baru semakin besar, sehingga orang akan lebih kreatif dan memiliki kemampuan. Dengan belajar seseorang dapat mewujudkan dirinya sendiri sehingga orang memiliki keinginan sesuatu secara tepat tanpa tergantung dengan orang lain.

d. Keluarga

Orang tua mempunyai peranan yang sangat penting dalam melatarkan dasar-dasar kepribadian seorang anak, demikian pula dalam pembentukan kemandirian pada diri seseorang.

e. Interaksi social

Kemampuan remaja dalam berinteraksi dengan lingkungan social serta mampu melakukan penyesuaian diri dengan baik akan mendukung perilaku remaja yang bertanggung jawab, mempunyai perasaan aman dan mampu menyelesaikan segala permasalahan 
yang dihadapi dengan baik tidak mudah menyerah akan mendukung untuk berperilaku mandiri.

Berdasarkan hasil wawancara dari kedua informan tersebut pada pertanyaan yang sama maka dapat disimpulkan bahwa bapak Mersik jualkan kerajinan tangan ini ada di pasar dan dirumah bapak sendiri.

\section{Kesimpulan}

Berdasarkan hasil temuan penelitian dilapangan dan teori-teori yang ada, dapat disimpulkan bahwa mengenai mengembangkan dan lansia dalam kerajinan tangan yang dijual di pasar tersebut merupakan hasil dari anyaman seperti (bubu, kinjar/kinjagh) yang dibuat Bapak Mersik sendiri, yang berawal berdirinya dari tahun 1997 dia mulai berkerajinan tangan berpenghasilan setiap bulan sekirat 500.000-1.000.000 lima ratus sampai dengan satu juta rupiah bersih setiap bulannya, selain kerajinan tangan beliau juga memiliki keahlian di bidang kesenian yaitu seni dendang.untuk memanfaatkan pohon bambu itu menjadi kerajinan rumah tangga dari ideh bapak mersik tadi usaha bapak berkembang dan bisa di jualkan ke pasar tradisional sehingga menghasilkan untung yang besar sampai bisa menyekolahkan anak bapak, selain itu juga sumber daya manusia mendukung dengan masyarakat dan anak yang sering kkn disini membantu promosikan hasil karya bapak,beserta anak dan istri yang selalu memberi semangat.

\section{Refernsi}

Basu Swastha. 2003. "Manajemen Pemasaran Modern". Yogyakarta : Liberty

Danim, Sudarwan. 2002. Penelitian Kuantitatif dan Kualitatif. Bandung :

Pustaka Setia DR.

Depdiknas. 2002. Kamus Besar Bahasa Indonesia. Jakarta : Balai Pustaka Ina Primiana 2006. Usaha Kecil dan Pengambangan. Banten : CiptaUsaha Imaculata Umiyati 2017. Ciri Kemandirian. Jawa Barat Yuwistara

Masrun. 1986. Faktor-faktor yang mempengaruhi pada remaja

Sofiah et all. 2011. Sektor Usaha dan Karakteristik. Jawa Tengah. PT Bagus Indah

Tjitrosoepomo. 1991.Kerajinan dan Kebudayaan. Semarang : Cv Kara Bagasti

UU No. 20 Tahun 2003 tentang Sistem Pendidikan Nasional

UUD RI No. 9 Tahun 1995 Tentang Usah Kecil. 